\author{
ACTA MYCOLOGICA \\ Vol. 47 (2): 139-143 \\ 2012
}

\title{
Is small mammal mycophagy relevant for truffle cultivation?
}

\author{
ALEXANDER URBAN ${ }^{1}$, MARIJA KATARŽYTÉ2 ${ }^{2}$, SUSANNE SCHICKMANN ${ }^{3}$, \\ KATHARINA KRÄUTLER ${ }^{4}$ and TONY PLA ${ }^{1,5}$
}

\author{
${ }^{1}$ Department of Systematic and Evolutionary Botany, Faculty of Life Sciences \\ University of Vienna, Rennweg 14, A-1030 Vienna, alexander.urban@univie.ac.at \\ ${ }^{2}$ Coastal Research and Planning Institute, Klaipeda University, LT-92294, Klaipėda \\ ${ }^{3}$ Department of Integrative Biology and Biodiversity Research, Institute of Wildlife Biology \\ and Game Management, University of Natural Resources and Life Sciences, \\ Gregor-Mendel-Strasse 33, A-1180 Vienna \\ ${ }^{4}$ Department of Forest and Soil Sciences, Institute of Forest Entomology, \\ Forest Pathology and Forest Protection \\ University of Natural Resources and Life Sciences, Hasenauerstraße 38, A-1180 Vienna \\ ${ }^{5}$ TrüffelGarten Urban \& Pla OG, Burwegstr. 88, A-3034 Eichgraben
}

Urban A., Kataržytė M., Schickmann S., Kräutler K., Pla T.: Is small mammal mycophagy relevant for truffle cultivation? Acta Mycol. 47 (2): 139-143, 2012.

The role of mycophagous small mammals as vectors of hypogeous fungi is well established. However, little is known about dispersal of gourmet truffle species by mammal vectors, or about the potential role of mycophagy in truffle plantations. We hypothesize that small mammal mycophagy contributes to the productivity of truffle plantations by providing inoculum for truffle mycelium establishment and mating. Spread of non-desired competitors of gourmet truffles is a potential adverse effect of small mammal mycophagy.

Keywords: Tuberaestivum, Tubermelanosporum, mutualism, symbiosis, mycorrhiza, ectomycorrhiza

\section{INTRODUCTION}

Hypogeous fungi and other macrofungi are part of the diet of small rodents (Rodentia) such as voles (Arvicolinae, Cricetidae, Myomorpha), mice (Murinae, Muridae, Myomorpha), dormice (Gliridae, Sciuromorpha) and sqirrels (Sciuridae, Sciuromorpha) (Maser, Claridge and Trappe 2008). Recently it was found that insectivorous shrews (Sorex spp., Soricidae, Eulipotyphla) frequently feed on hypogeous fungi as well (Kataržytė, Kutorga 2011; Schickmann et al. 2012). The nutritional ecology of most small mammal species seems to be rather flexible, highly adaptive and more diverse than commonly assumed. Spore dispersal in hypogeous fungi including 
gourmet truffle species depends entirely on animal vectors, and the mutualistic relationship between mycophagous animals and hypogeous fungi can be considered obligate for the latter. Small mammal mycophagy was extensively studied in North America and Australia, since it was recognized as a process potentially important for the maintenance of fungal and mammal biodiversity and for forest regeneration (Claridge 2002; Maser et al. 2008). In Europe, relatively few studies demonstrated the role of mycophagy in bank vole, (Myodes glareolus, Blaschke and Bäumler 1989), red squirrel (Sciurus vulgaris, Grönwall, Pehrson 1984; Bertolino et al. 2004) and wood mice (Apodemus spp., Blaschke, Bäumler 1989).

During a study conducted in primary and secondary forests in two regions of the eastern alps we found that all mammal species native to Central Europe mountainous forests investigated feed on hypogeous fungi, albeit with different intensity (Schickmann et al. 2012). Based on frequency, quantity and diversity of fungal spores detected in faeces by microscopy and with molecular tools, we concluded that at least one native small mammal species, the bank vole (Myodes glareolus) is preferentially mycophagous. All other species captured, including wood mice ( $A p$ odemus flavicollis and $A$. sylvaticus), other vole species, shrews (Sorex spp.) and the fat doormouse (Glis glis) were found to be opportunistically mycophagous. All small mammal species were found to feed on a diversity of fungal species. Similar results were reported from hemiboreal forests in Lithuania (Kataržytė, Kutorga 2011).

\section{METHODS}

Here we synthesize available information to infer potential roles of small mammals in truffle plantations. A descriptinon of methods used for life trapping of small mammals, fecal pellet sample collection and microscopical analysis is found in (Schickmann et al. 2012). A protocol optimized for DNA extraction from fungal spores in fecal pellets of small mammals was developed (Schickmann et al. 2011).

\section{RESULTS}

POTENTIAL ROLES OF SMALL MAMMALS IN TRUFFLE PLANTATIONS

Effects on host trees. Small mammal communities differ with habitat types. Rodent species are more or less herbivorous, and some species are known to damage host trees, at least at high population densities. Red squirrels are likely to occur in mature plantations, especially if hazelnuts (Corylus spp.) or conifer seeds are available. Squirrels are very effective seed predators, hoarding of excess food in caches contributes to seed dispersal. Sqirrels can damage trees by bark stripping, however, this behaviour is a major issue in the invasive grey squirrel (Sciurus carolinensis) but not in the native red squirrel (Bertolino, Genovesi 2003). Voles can cause severe damage in young truffle plantations. Newly established truffle plantations in 
agricultural environmenments are more likely to be colonized by common voles (Microtus arvalis) than by species ocurring in more natural habitats such as field vole (Microtus agrestis) and bank vole (Myodes glareolus). An invasion of voles into an experimental truffle plantation was observed when a neighbouring maize field was harvested and the animals lost shelter (Ronald Vogl, personal communication). Debarking of the stem base killed one Corylus colurna tree (4 yrs after outplanting). It appears that some tree species are less preferred by voles, e.g., pine species are avoided (Borowski 2007). Lime tree (Tilia cordata) seedlings were reported to be preferentially attacked by bank voles (Pigott 1985).

Planting a diversity of tree species may the best strategy to limit overall damage, given the diversity of potential pest species. According to our experience, voles are rarely a cause of excessive tree mortality in truffle plantations, but pressure can vary considerably. If the risk of loosing tree seedlings due to damage by voles is high, the roots and stem bases can be protected with a non-galvanized wire-basket which will decompose by corrosion. Mulching can provide shelter for small mammals depending on the material used and should be avoided or adapted if pressure is critical.

Small mammal species are an important source of prey for predators such as various species of birds of prey, owls, red fox (Vulpes vulpes), wildcat (Felis silvestris), and various mustelids such as weasel (Mustela nivalis), European polecat (Mustela putorius) and European badger (Meles meles). Providing habitat for predators and protecting them from beeing hunted is an effective way to keep small mammal populations at levels compatible with plantation management objectives.

According to our experience, game species, like European hare (Lepus europaeus) and roe deer (Capreolus capreolus) usually impose much higher pressure on young truffle plantations and need to be excluded.

Effects on truffle populations. Little is known about effects of mycophagy on truffle populations in managed plantations. The small rodent species common in habitats like truffle plantations, e.g., voles, wood mice (Apodemus syvaticus and $A$. flavicollis) and squirrels are well known to be mycophagous (Maser et al. 2008). Sqirrels even cache hypogeous fungi (Vernes, Poirier 2007). Recently it was shown that also insectivores such as shrews (Sorex spp.) frequently feed on hypogeous fungi (Kataržytė, Kutorga 2011; Schickmann et al. 2012). This result is of interest for two reasons: 1) Shrews are not herbivorous and they are very unlikely to harm host trees. 2) Shrews are insectivorous and ground-dwelling, and may contribute to controlling insects parasitic on truffles or host tree roots.

From the truffle growers perspective, mycophagy may be regarded as a waste of valuable crop. Small mammals are important dispersal agents for truffle spores, but no data are available which proof that there is a role for mycophagist in plantations established with mycorrhized trees. Once established, genets of truffle mycelium can grow and and extend, without apparent need of additional spores. However, three lines of evidence suggest that mycophagy may be essential for the long term fertility and productivity of truffle plantations: 1) Truffle spores in faeces of small mammals are a viable source of inoculum (Schickmann et al. 2012). 2) Artificial inoculation of soil with truffle spores is reported to inrease yields of Tuber aestivum (P. Sourzat, unpublished). 3) Sexual reproduction and outcrossing has been proven in some gourmet truffle species (Paolocci et al. 2006; Riccioni et al. 2008), and ascopore or 
conidiospore (Urban et al. 2004) dispersal is likely to play a role in fertilisation of opposing mating types.

Truffle spore dispersal by small mammal vectors has one potential drawback: mycophagists use to feed on a variety of species of hypogeous fungi. Thereby, they likely vector non-marketable or low-value species which may compete with the target gourmet truffle within the plantation.

\section{CONCLUSIONS}

Currently, information on the role of small mammal mycophagists in truffle plantations is scarce, despite the significance of mycophagy in the truffle life cycle. Small mammals, at least if present in excess, are typically regarded as pests, by foresters and truffle-growers. Some truffle growers use to combat small mammals by different means of pest control, but systematic experimentation is still lacking. At present we do not know whether the contribution of spore dispersal by small mammals to productivity is comparable to the relevance of pollination in fruit orchards. The impact of biotic interactions on productivity is more difficult to assess than the influence of abiotic factors, such as climate. Experimental work on mycophagy in truffle plantation and natural truffle sites is needed to obtain reliable data on the role of small mammals in the dispersal and reproduction of truffle species.

\section{REFERENCES}

Bertolino S., Genovesi P. 2003. Spread and Attempted Eradication of the Grey Squirrel (Sciurus carolinensis) in Italy, and Consequences for the Red Squirrel (Sciurus vulgaris) in Eurasia. Biological Conservation 109: 351-358. doi:10.1016/S0006-3207(02)00161-1.

Bertolino S., Vizzini A., Wauters L.A., Tosi G. 2004. Consumption of Hypogeous and Epigeous Fungi by the Red Squirrel (Sciurus vulgaris) in Subalpine Conifer Forests. Forest Ecology and Management 202: 227-233. doi:10.1016/j.foreco.2004.07.024.

Blaschke H. \& Bäumler. W. 1989. Mycophagy and Spore Dispersal by Small Mammals in Bavarian Forests. Forest Ecology and Management 26: 237-245. doi:10.1016/0378-1127(89)90084-4.

Borowski Z. 2007. Damage Caused by Rodents in Polish Forests. International Journal of Pest Management 53: 303-310. doi:10.1080/09670870701497253.

Claridge A. W. 2002. Ecological Role of Hypogeous Ectomycorrhizal Fungi in Australian Forests and Woodlands. Plant and Soil 244: 291-305. doi:10.1023/A:1020262317539.

Grönwall O., Pehrson A. 1984. Nutrient Content in Fungi as a Primary Food of the Red Squirrel Sciurus vulgaris L. Oecologia 64: 230-231. doi:10.1007/BF00376875.

Kataržytė M., Kutorga E. 2011. Small Mammal Mycophagy in Hemiboreal Forest Communities of Lithuania. Central European Journal of Biology 6: 446-456. doi:10.2478/s11535-011-0006-z.

Maser C. A., Claridge A.W., Trappe J. M. 2008. Trees, Truffles, and Beasts: How Forests Function. Rutgers University Press.

Paolocci F., Rubini A., Riccioni C., Arcioni S. 2006. Reevaluation of the Life Cycle of Tuber magnatum. Applied and Environmental Microbiology 72: 2390-2393. doi:10.1128/AEM.72.4.2390-2393.2006.

Pigott C. D. 1985. Selective Damage to Tree-seedlings by Bank Voles (Clethrionomys glareolus). Oecologia 67: 367-371. doi:10.1007/BF00384942. 
Riccioni C., Belfiori B., Rubini A., Passeri V., Arcioni S., Paolocci F. 2008. Tuber melanosporum Outcrosses: Analysis of the Genetic Diversity Within and Among Its Natural Populations Under This New Scenario. New Phytologist 180: 466-478. doi:10.1111/j.1469-8137.2008.02560.x.

Schickmann S., Kräutler K., Kohl G., Nopp-Mayr U., Krisai-Greilhuber I. Hackländer K., Urban A. 2011. Comparison of Extraction Methods Applicable to Fungal Spores in Faecal Samples from Small Mammals. Sydowia 63: 237-247.

Schickmann S., Urban A., Kräutler K., Nopp-Mayr U., Hackländer K. 2012. The Interrelationship of Mycophagous Small Mammals and Ectomycorrhizal Fungi in Primeval Disturbed and Managed Central European Mountainous Forests. Oecologia 170: 395-409. doi:10.1007/s00442-012-2303-2.

Urban A., Neuner-Plattner I., Krisai-Greilhuber I., Haselwandter K. 2004. Molecular Studies on Terricolous Microfungi Reveal Novel Anamorphs of Two Tuber Species. Mycological Research 108: 749-758.

Vernes K., Poirier N. 2007. Use of a Robin's Nest as a Cache Site for Truffles by a Red Squirrel. Northeastern Naturalist 14: 145-149. doi:10.1656/1092-6194(2007)14[145:UOARNA]2.0.CO;2. 